\begin{tabular}{c} 
Volume and Issues Obtainable at Center for Sustainability Research and Consultancy \\
Sustainable Business and Society in Emerging Economies \\
ISSN: $2708-2172$ (E): $2708-2504$ \\
Volume 2: Issue 2 December 2020 \\
Journal homepage: $\underline{w w w . p u b l i s h i n g . g l o b a l c s r c . o r g / s b s e e}$ \\
\hline
\end{tabular}

\title{
Determinants of Liquidity Considering Role of Market Competition; Evidence from Pakistan's Banking Sector
}

\author{
${ }^{1}$ Amir Rafique, ${ }^{2}$ Muhammad Adeel, ${ }^{3}$ Kalsoom Akhtar, ${ }^{4}$ Muhammad Amir Alvi \\ ${ }^{1,2 \& 4}$ Department of Management Sciences, COMSATS University Islamabad, Pakistan, \\ amir.rafique@comsats.edu.pk \\ ${ }^{3}$ Institute of Business, Management and Administrative Sciences, The Islamia University of Bahawalpur, \\ Pakistan, kalsoom.akhtar@iub.edu.pk
}

\begin{tabular}{l}
\hline ARTICLE DETAILS \\
\hline History: \\
Revised format: November, \\
2020 \\
Available Online: December, \\
2020 \\
\hline Keywords: \\
Credit Risk, Liquidity, \\
Market Competition, HHI \\
Index
\end{tabular}

JEL Classification:

M11,M12

\begin{abstract}
Current study empirically analyzes specific macroeconomic and bank factors that determine the liquidity reserves of banks functioning in Pakistan. To highlight the association, current study performed random effects estimates on a data set of 20 banks from 2006 to 2016. Factors related to bank includes capital, credit Risk and bank size. GDP and Inflation are the macroeconomic factors that were considered. Market competition has been measured through HHI. As per panel data analysis, current study suggests that bank specific factors (except capital), macroeconomic factors and market competition significantly affect liquidity reserves of banks in Pakistan. These factors include bank size, credit risk, market competition, inflation and GDP. In addition, a negative effect of bank size, credit risk, GDP and Inflation have been identified on bank liquidity. Moreover, on bank liquidity market competition positive effect has been found in this study. Further, study found insignificant effect of capital on bank liquidity.
\end{abstract}

(C) 2021 The authors, under a Creative Commons AttributionNonCommercial 4.0

Corresponding author's email address: amir.rafique@comsats.edu.pk

Recommended citation: Rafique, A., Adeel, M., Akhtar, K. \& Alvi, M. A. (2020). Determinants of Liquidity Considering Role of Market Competition; Evidence from Pakistan's Banking Sector. Sustainable Business and Society in Emerging Economies, 2 (2), 51-59

\section{Introduction}

Global financial crisis unveiled liquidity importance for smooth financial markets and banks functioning (Vodova, 2013). These crises unveiled loopholes in practices to manage liquidity risk of individual bank. Bank with good quality assets, handsome earning and ample capital might collapse if it does not maintain ample liquidity reserves (Chaplin et al., 2000). Liquidity risk affect both performance and good will of bank (Jenkinson, 2008). Banks should brace themselves to tackle the changes in monetary policy that determines the overall liquidity movements, repayment of short-term borrowings and banks own transactional requirements (Akhtar, 2007). The ample level of liquidity has strong linkage with effective operation of a bank. Mismanagement of liquidity could result in insolvency (having low liquidity) and 
low profitability (having surplus liquidity). It could, in turn, have negative effect on shareholder value and might spur contagion effect (Moussa, 2015).

The Basel Committee on Banking Supervision (BCBS) (2010) stressed banks liquidity creation and their solvency by maintaining high pool of capital reserves by banks. Liquidity of banks is determined by many types of variables including Bank Specific; Macroeconomic and market competition variables. Present study combines banks specific, market competition and macroeconomic factors as dependent variable and attempts to highlight impact of these factors on liquidity of commercial banks which yield valuable insights. According to Dinger (2009) and Sing and Sharma (2016) bank size has significant negative relationship with liquidity it could be a vital determinant of its liquidity. Bhati et al. (2015) asserted that capital negatively affect liquidity of banks. Acharya et al. (2011) suggest that ultimately high capital reserves help banks to create more liquidity by granting more loans and taking higher risk. Megeid (2017) explain that expansion in assets by banks could increase credit risk which might be simultaneously increasing its liquidity risk. They further add that bank's liquidity position could be negatively influenced by huge loan's default. The theory of bank liquidity and financial fragility state that high GDP growth indicates an increase in business activities, which affect banks liquidity negatively as banks expand its loans and verse versa. Bhati et al. (2015) found the negative influence of inflation rate on banks liquidity. They claim that banks keep more reserves of liquid assets during economic downturn and low reserves of liquid assets during economic boom. Structural changes in banking sector have influenced competition of banking sector. Less competitive market coupled with the presence of larger banks provide higher "capital buffers" that provide shield to these systems from external macroeconomic and liquidity turmoil. Consequently, this leads towards increase in the profit margins and reduction in the financial fragility (Boyd et al., 2004). Less competitive market shows the presence of market power. Bunda and Desquilbet (2008) claimed that high level of efficiency and profitability has association with the higher degree of market power.

Many studies in Pakistan shed light on determinants of liquidity. These studies analyze the impact of bank specific and macroeconomic variables but do not highlight the impact of market competition on liquidity of banks. Structural changes in banking industry have changed the level of competition in banking industry therefore, this study considered the impact of market competition on liquidity pool of commercial banks functioning in Pakistan. Hence this study provides valuable insights by highlighting relationship between market competition and liquidity of banks. Objectives of this study are to examine the impact of bank specific factors (size, capital and credit risk), macroeconomic variables (inflation and GDP) and market competition (HHI) on liquidity of banks in Pakistan. The paper is organized as follows. Section 2 provides critical review of literature. Section 3 describes methodology. Section 4 discusses results and discussion. Final section concludes the paper.

\section{Literature Review}

Extensive literature is available on liquidity of banks and its bank specific and macroeconomic determinants. In this study we estimated the relationship between bank specific factors include bank size, capital and credit Risk, macroeconomic factors GDP and Inflation and Market competition on liquidity of banks functioning in Pakistan. Literature regarding these factors is given as follow.

The Basel Committee on Banking Supervision (2008) defines liquidity as "the ability of bank to fund increases in assets and meet obligations as they come due, without incurring unacceptable losses". Dinger (2009) claimed that liquid banks are foremost important to keep the economy smoothly functioning. During recent financial turmoil, many banks scuffle to maintain ample level of liquidity. To keep financial system functioning, exceptional liquidity support was needed from central banks (Cernohorský et al., 2010).

\subsection{Size and Bank Liquidity Relationship}

Sing and Sharma (2016) claimed negative relationship between liquidity of bank and its size. In other words, large banks keep less resources of liquidity while small banks keep high resources of liquidity. 
They supported their findings by explaining that this inverse relationship is might be due to ability of large banks to access lender of last resort more easily than small banks during crisis. They further explained that small banks need to maintain high liquidity resources than big banks as they might not be able to access funds as easily as larger banks do. Zaghdoudi and Abdilaziz (2017) also supported findings of Sing and Sharma (2016). T1hey also claimed that there is negative relationship between size of bank and liquidity risk. In other words, small banks are more prone to liquidity risk. They explain that this negative relationship is because of lack of supervision which in turn restricts their negotiation abilities in various markets. Consequently, they turn to banking intermediation, which affect lead them to liquidity crunch. Findings of Dinger (2009), Distinguin et al. (2013), Angora and Roulet (2011) studies also unveiled that bank size has significant negative relationship with liquidity and banks size.

$H_{1}$ : Size of bank has significant negative relationship with liquidity of bank.

\subsection{Capital and Bank Liquidity Relationship}

Repullo (2005) concluded that higher capital requirement induce banks to reduce risk levels in loan portfolio which subsequently reduces its liquidity. Horvath et al. (2014) highlighted the relationship between liquidity creation and capital. They asserted that small banks having high capital resources created less liquidity while on the other hand large banks with ample capital kept on creating more liquidity. Bhati et al. (2015) suggested that ample level of capital helps banks to face losses and strengthen its solvency. Banks having ample capital resources also have easy access to financial markets and can tackle liquidity issues sparked by outflow of funds. They also claim that capital refrain them from risk taking. Studies of Acharya et al. (2011), Jokipii and Milne (2011), and Vodova (2011) also estimated similar results. But study of Berger and Bouwman (2009) gives opposite results, as they mentioned that high capital resources facilitate banks to create more liquidity. In addition, this capital also enables banks to bear risk boldly.

$\mathrm{H}_{2}$ : Capital has significant negative relationship with liquidity of bank.

\subsection{Credit Risk and Bank Liquidity Relationship}

Brown and Moles (2012) defined credit risk as "the potential that a contractual party will fail to meet its obligations in accordance with the agreed terms". Diamond and Rajan, (2005) argued that bank failures could diminish common liquidity reserves. Consequently, aggregate liquidity shortage arises. Zaghdoudi and Abdelaziz (2017) claimed that credit risk has significance and positive relationship with liquidity risk. They claimed this relationship with respect to depositor's demand. They stated that bank cannot satisfy depositor's demand if bank finance enormous distressed economic projects. They further explained that depositors commence withdrawing their deposits if these assets start declining their value. Therefore, higher credit risk give rise to higher liquidity risk via depositor's demand. Therefore, higher liquidity risk will decrease liquid reserves of bank. Diamond and Rajan (2005), Arif and Anees, (2012), Louati et al. (2015) and Ghosh, (2016) also argue in favour of significant relationship between credit risk and liquidity. $\mathrm{H}_{3}$ : Credit risk has significant negative relationship with liquidity of bank.

\subsection{Market Competition and Bank Liquidity Relationship}

Over the recent decades, economic authorities across the globe have initiated structural changes in banking industry which in turn have sparked changes in the structure and level of competition in banking industry (Kouki \& Al-Nasser, 2017). Boyd et al. (2004) suggested that large banks in less competitive markets provide excessive capital buffer that shields these systems from macroeconomic and liquidity blows Thus, banks hold less liquidity resources in less competitive markets. Price competition also has association with liquidity of banks. Almarzoqi et al. (2015) observed positive relationship between price competition and liquidity. They argued that price competition induce a self-discipline mechanism on the choice of bank's funding sources which results in high liquid resources. They further added that banks reduce their profit margin in stiff competitive environment and consequently, they cannot afford expensive funding sources. Thus, they hold larger amount of liquid assets. Tan et al. (2017) suggested that competition should be control to a particular point in order to avoid liquidity risk, credit risk and capital 
risk. Horvath et al. (2016) shed light on effect market competition on liquidity of creation of banks. They claimed that stiff competition among banks result in less liquidity creation, because increased bank competition on the financial fragility of banks, as a result banks reduce their lending and deposit activities. They also suggested that pro-competitive policies in the banking industry can reduce liquidity provision by banks.

$H_{4}$ : Market competition has significant positive relationship with liquidity of banks.

\subsection{Economic Growth and Bank Liquidity Relationship}

The theory of bank liquidity and financial fragility states that high GDP growth indicates an increase in business activities, which affect banks liquidity negatively as banks expand its loans. Extensive literature is available that shed light on relationship between GDP and liquidity of banks. Findings of these studies are not common as some studies show positive relationship between liquidity and GDP while other show negative relationship between GDP and liquidity of banks. Choon et al. (2013); Bunda and Desquilbet (2008) highlighted positive relationship between GDP and bank liquidity while Valla et al. (2006), Dinger (2009), Vodova (2011), and Trenca et al. (2015) estimated negative relationships. Sing and Sharma (2016) also claimed that liquidity has significant negative relationship with GDP. They explained their findings by mentioning that during economic downturn, banks keep higher resources of liquidity because of lending opportunity as they lack at such time. Zaghdoudi and Abdelaziz (2017) identified the GDP and liquidity risk relationship. They claimed that GDP affect liquidity risk significantly positively. They argued that economic growth results in higher income of households in an economy. Consequently, they go for specialized financial services like leasing, housing loans and consumer loans, which in turn decreases liquidity resources of banks. Hence, there is negative relationship between GDP and liquidity. $H_{5}$ : Economic Growth has significant negative relationship with liquidity of bank.

\subsection{Inflation and Bank Liquidity Relationship}

In literature findings of many studies are ambiguous as some studies showed positive relationship between liquidity and inflation while other showed negative relationship between inflation and liquidity of banks. Bhati et al. (2015) in context of India also revealed negative relationship between inflation rate and liquidity reserves of banks. They supported their findings by stating that banks hold ample resources of liquid assets to maintain economic stability and flow of liquidity in the system when inflation rate falls and they keep less liquid assets when inflation is rises. Trenca et al. (2015) also studied the impact of macroeconomic factors on liquidity reserves of banks. Findings of their study revealed negative relationship between inflation and liquidity resources of banks. They argued that increase in inflation in an economy decrease purchasing power of residents of that economy. Consequently, they need more money to shop same products. This might sparks increase in lending of banks operating in that country which in turn lowers liquid assets of banks. While studies of Tseganesh, (2012), found positive impact of inflation on liquidity. Furthermore, Horváth et al. (2014) stated inflation insignificant effect on the liquid assets of bank.

\section{$H_{6}$ : Inflation has significant negative relationship with liquidity of bank.}

Extensive literature is available that shed light on liquidity of banks and its bank specific and macroeconomic determinants (Sing \& Sharma, 2016; Zaghdoudi \& Abdilaziz, 2017; Horvath et al., 2014; Berger \& Bouwman, 2009 and Ghosh, 2016). However, these studies do not capture the impact of market competition on liquidity of banks. In recent past, many structural changes have been implemented in banking industry. Large banks in less competitive markets provide capital support to banks which refrain them from macroeconomic and liquidity turmoil (Boyd et al., 2004). Considering the importance of market competition, this study fills this gap and attempts to highlight impact of market competition on liquidity of banks in operating in Pakistan. 


\section{Data and Methodology}

This study takes 20 commercial banks of Pakistan for the period of 2006-2016. Data on bank specific variables including size, capital and credit risk has been collected from Annual statements of banks, consolidated statements of financial sector whereas Macroeconomic variables like GDP and inflation has been taken from world bank and IMF sources. Macroeconomic variables included Inflation and GDP while industry competition variable: Herfindahl-Hirschman-Index on liquidity was considered. In order to attain aforementioned objective following Econometric model is proposed.

$$
L I Q_{i, t}=\beta_{0}+\beta_{1} \cdot \mathrm{SIZE}_{i, t}+\aleph_{2} \cdot \mathrm{CAP}_{i, t}+\beta_{3} \cdot \mathrm{CR}_{i, t}+\beta_{4} \cdot \mathrm{HHI}_{i, t}+\aleph_{5} \cdot \mathrm{EG}_{i, t}+\aleph_{6} \cdot \mathrm{INF}_{i, t}+e_{i, t+1}
$$

Where $\beta_{1}, \beta_{2}, \beta_{3}, \beta_{4}, \beta_{5}$, and $\beta_{6}$ are the coefficients of determinant variables and $e_{i, t+1}$ is error term, $L I Q_{i, t}$ is liquidity, $\operatorname{SIZE}_{i, t}$ is size of the bank, $\mathrm{CAP}_{i, t}$ is capital $\mathrm{CR}_{i, t}$ is credit risk, $\mathrm{HHI}_{i, t}$ is HerfindahlHirschman-Index, $\mathrm{EG}_{i, t}$ is economic growth, and $\mathrm{INF}_{i, t}$ is Inflation.

Following Sing and Sharma (2016), bank liquidity will be calculated as the ratio of liquid assets to total assets. Liquidity as dependent variable and remaining all have been included as explanatory variables in current study. Credit extension is core activity of a bank; this function gives rise to credit risk because of failure of its borrowers to honor their commitments with bank. It is measured by total loans to total assets (Hakimi \& Zaghdoudi, 2017). Size of the bank could possible affect liquidity risk of the bank. It is measured by natural logarithm of total assets of each bank (Melese \& Laximikantham,2015). Bank capital is often defined in tiers or categories that include shareholders' equity, retained earnings, reserves, hybrid capital instruments, and subordinated term debt. Following Bonfim and Kim (2011); Horvath et al. (2014), this study uses equity and total assets as the proxy of capital. Herfindahl-Hirschman Index (HHI) is a proxy measuring level of competition in industry/market. It is calculated by summing up the squared market shares of all commercial banks in an industry. Following Zaghdoudi and Abdelaziz (2017) this study uses total assets to calculate the market share.

Economic growth is measured by annual growth rate of GDP. GDP growth indicates an increase in business activities, which affect banks liquidity negatively as banks expand its loans and verse versa. Inflation represents increase in price of goods and services over time and consequently purchasing power of monetary unit reduces. It is measured by consumer price index (Zaghdoudi \& Abdelaziz, 2017).

\section{Results and Discussion}

Table 1 provides the descriptive statistics of all the variables. The mean value of Liquidity is 8.995 and it lies between 3.91 and 26.91 with the standard deviation of 3.380. The mean value of Size is 19.169 and it is in between 15.56 and 21.64 with standard deviation of 1.30.The mean value of Credit Risk is 45.15. It has minimum value 13.49 and maximum value 70.85 and standard deviation 10.42 . The mean value of Equity is 10.55 and it lies between -2.48 to 54.31 with standard deviation of 8.51 . The mean value of Market Competition is 938.69 and it ranges from 907.19 to 980.3 with the standard deviation of 22.61. The mean value of Economic Growth is 3.90 and it ranges from 1.61 to 6.18 with standard deviation of 1.46. The mean value of Inflation is 9.65 with maximum value 20.29 and minimum value 2.54 and standard deviation of 4.82 .

Table 1: Summary Statistics (2006-2016)

\begin{tabular}{lcccc}
\hline Variables & Mean & Minimum & Maximum & $\begin{array}{c}\text { Standard } \\
\text { Deviation }\end{array}$ \\
\hline Liquidity & 8.995 & 3.91 & 26.91 & 3.380 \\
Size & 19.17 & 15.56 & 21.64 & 1.3 \\
Capital & 10.55 & -3.10 & 54.31 & 8.503 \\
Credit risk & 45.15 & 13.49 & 70.86 & 10.43 \\
Market competition & 938.7 & 907.2 & 980.30 & 22.62 \\
Economic growth & 3.903 & 1.61 & 6.18 & 1.47 \\
Inflation & 9.646 & 2.54 & 20.28 & 4.82 \\
\hline
\end{tabular}

Correlation analysis highlights the relationship between dependent variable and explanatory variables. 
The range of correlation co efficient is always between -1 and +1 .Two variables are perfectly positively related when their correlation coefficient is +1 . Two variables are perfectly negatively correlated related when their correlation coefficient is -1 . When correlation efficient is zero means there is no correlation between variables.

Table 2: Correlation Matrix

\begin{tabular}{|c|c|c|c|c|c|c|c|}
\hline & Liquidity & Size & Capital & $\begin{array}{l}\text { Credit } \\
\text { risk }\end{array}$ & $\begin{array}{l}\text { Market } \\
\text { competition }\end{array}$ & $\begin{array}{l}\text { Economic } \\
\text { growth }\end{array}$ & Inflation \\
\hline Liquidity & 1 & & & & & & \\
\hline Size & 0.0411 & 1 & & & & & \\
\hline Capital & -0.113 & -0.429 & 1 & & & & \\
\hline Credit risk & -0.027 & 0.009 & -0.116 & 1 & & & \\
\hline $\begin{array}{l}\text { Market } \\
\text { competition }\end{array}$ & 0.324 & -0.168 & 0.0383 & 0.225 & 1 & & \\
\hline Economic growth & -0.0521 & 0.067 & 0.011 & -0.197 & 0.314 & 1 & \\
\hline Inflation & -0.153 & -0.211 & 0.0261 & 0.362 & 0.0983 & -0.0842 & 1 \\
\hline
\end{tabular}

Correlation table shows that there is no multicollinearity issue among variables as correction values among the variables are low. Credit Risk has weak negative correlation with liquidity as its correlation value with liquidity is -0.0270 . Similarly, economic growth has weak negative correlation of 0.0521 with liquidity. On the other hand, size has weak positive correlation of 0.0411 with Liquidity respectively. Capital has modest negative correlation with liquidity as its correlation value with liquidity is -0.113 . Market competition has moderate positive orrelation with liquidity as its correlation value with liquidity is 0.3240. Inflation has modest negative correlation with liquidity as its correlation value with liquidity is 0.153 .

Following Hausman test, current study applies random effect model. Results of analysis are shown in the table 3.

Table 3: Random Effect Model

Dependent variable: Bank Liquidity

\begin{tabular}{lrrrr}
\hline Variable & Coefficients & Std. Error & \multicolumn{1}{c}{ t-value } & p-value \\
\hline Size & -0.940251 & 0.279805 & -3.360383 & 0.0009 \\
Capital & -0.019824 & 0.023412 & -0.846755 & 0.3981 \\
Credit risk & -0.034599 & 0.019499 & -1.774346 & 0.0774 \\
Market competition & 0.022360 & 0.009354 & 2.390381 & 0.0177 \\
Economic growth & -0.750397 & 0.281269 & -2.667903 & 0.0082 \\
Inflation & -0.264183 & 0.089034 & -2.967226 & 0.0033 \\
\hline & & & F- statistic & 13.450 \\
& & & Prob > F & 0.000 \\
& & & R-sq: & 0.275 \\
\hline
\end{tabular}

F- Statistics has significant p-value which is indicating that model is over all significant. The coefficient of Size is -0.940251 which is significant which indicates that increase in size of banks decrease its liquidity. Thus it leads towards acceptance of $H_{1}$ which states size has significant negative relationship with liquidity. This result is in line with Sing and Sharma (2016) who explained that small banks need to maintain high liquidity resources than big banks as they might not be able to access funds as easily as larger banks do. Capital shows insignificant result it means there is no significant relationship between capital and liquidity of banks. Thus, it leads towards rejection of $H_{2}$ which states capital has significant negative relationship with liquidity. Credit risk has significant relationship with liquidity thus we accept $\mathrm{H}_{3}$ which states that credit risk has significant relationship with liquidity. The coefficient of credit risk is 0.034599 which indicates that increase in credit risk of banks decrease its liquidity. This result is consistent with Zaghdoudi and Abdelaziz (2017) who claimed that with the increase in credit risk, 
liquidity of bank commences to vanish which in turn could possibly result in collapse of bank. The coefficient of Market competition is 0.02236 which is significant. It means market competition significantly explains liquidity of banks and thus, it leads towards acceptance of $H_{4}$ which states market competition has significant positive relationship with liquidity. This finding affirms finding of Almarzoqi et al. (2015) positive relationship between price competition and liquidity They argued that price competition induce a self-discipline mechanism on the choice of bank's funding sources which results in high liquid resources. Economic growth has also significant relationship. It means there is significant relationship between economic growth and liquidity of banks. Thus, it leads towards acceptance of $H_{5}$ which states Economic Growth has significant negative relationship with liquidity. The coefficient of credit risk is -0.750397 which indicates that increase in economic growth decreases liquidity of banks. These results are consistent with Sing and Sharma (2016) who claimed that liquidity has significant negative relationship with economic growth. Coefficient of Inflation is -0.264183 which is significant. It means inflation significantly explains liquidity of banks and thus it leads towards acceptance of $H_{6}$ which states that size has significant negative relationship with liquidity. This finding of study is supporting the findings of Bhati et al. (2015) who argued that banks keep higher liquid assets as inflation rates reduces and vice versa. They hold higher liquidity during economic downturn to provide support to economy to make it stable and to ensure flow of liquidity economy. Value of R-square is 0.2748 which is significant and depict that means $27.48 \%$ changes in dependent variable (Liquidity) are because of dependent variables (Size, Capital, Credit Risk, Market Competition, Economic Growth and Inflation).

\section{Conclusion}

The purpose of this study is to shed light on determinants of liquidity of banks in Pakistan. The recent global recession of 2007-08 has revealed the importance liquidity management for banking industries across the globe. Consequently, it grabbed attention of researchers, policy makers and regulators around the world. In recent past, banking industry across globe has witnessed structural changes. These changes have led the change in level of competition prevailing in those industries. Consequently, these variations in level of competition change liquidity reserves of banks competing in those industries. Keeping in view the importance of market competition, the prime inspiration of this study is to highlight the relationship between market competition and liquidity of banks as this relationship has not grabbed ample attention from in previous studies. Another inspiration of conducting this study is lack of consensus in literature concerning determinants of liquidity of banks. Thus, this study attempts to highlight various flavors of determinants of liquidity of banks in Pakistan: Bank specific, macroeconomic and market competition.

The first hypothesis states that there is significant negative relationship between size of bank and liquidity of bank. Findings of study affirm this hypothesis and unveils size has significant negative relationship with liquidity of banks it means increase in size decreases liquidity. Second hypothesis is formulated to highlight the relationship between capital and liquidity of banks. This hypothesis states that there is significant negative relationship between capital and liquidity of banks. Results of study negate this hypothesis and show no significant relationship between capital and liquidity of banks. Third hypothesis is formulated to highlight the relationship between credit risk and liquidity of banks. This hypothesis states that there is significant negative relationship between credit risk and liquidity of banks. This study finds significant negative relationship between credit risk and liquidity. It means increase in credit risk decreases liquidity of banks. Fourth hypothesis states that there is significant relationship between market competition and liquidity of bank. Findings of study affirm this hypothesis and unveils that market competition has significant positive relationship with liquidity of banks. It means increase in market competition leads towards increase in liquid resources of banks. Fifth hypothesis is formed to highlight the relationship between GDP and liquidity of banks. This hypothesis states that there is significant negative relationship between GDP and liquidity of banks. Results of study accept this hypothesis and shows significant negative significant relationship between GDP and liquidity of banks. Sixth and final hypothesis is formulated to highlight the relationship between inflation and liquidity of banks. This hypothesis states that there is significant negative relationship between inflation and liquidity of banks. This study finds significant negative relationship between inflation and liquidity. It means increase in inflation decreases liquidity of banks. 
The finding of present study unveils significant positive relationship between market competition and liquidity. This significant relationship of market competition with liquidity shown in this study will be valuable for researchers shedding light on this relationship. It will also provide guidelines to managers and policy makers while formulating policies and strategies regarding liquidity management. Current study shed light on relationship between liquidity and its three different sets of determinants: Bank specific variables, macroeconomic variables and market competition variable. This study calculated market competition through HHI. Future studies can use non-structural measure of competition like Lerner-Index and H-Statistics to highlight relationship between competition and liquidity. Moreover, this study calculated HHI on the basis of assets; future studies can calculate HHI on the basis of deposits and loans.

\section{References}

Abdel Megeid, N. S., \& Abdel Megeid, N. S. (2017). Liquidity risk management: conventional versus Islamic banking system in Egypt. Journal of Islamic Accounting and Business Research, 8(1), 100128.

Acharya, V. V., Viswanathan, S., Leverage, Moral Hazard and Liquidity, Journal of Finance 66 (2011) 99-138.

Akhtar, S. (2007). Pakistan: changing risk management paradigm-perspective of the regulator. In ACCA Conference-CFOs: The Opportunities and Challenges Ahead, Karachi (p. 8).

Almarzoqi, R., Naceur, S. B., \& Scopelliti, A. D. (2015). How Does Bank Competition Affect Solvency, Liquidity and Credit Risk?

Angora, A., \& Roulet, C. (2011). Transformation risk and its determinants: A new approach based on the Basel III liquidity management framework. Universite de Limoges.

Arif, A., \& Nauman Anees, A. (2012). Liquidity risk and performance of banking system. Journal of Financial Regulation and Compliance, 20(2), 182-195.

Berger, A. N., Klapper, L. F., \& Turk-Ariss, R. (2009). Bank competition and financial stability. Journal of Financial Services Research, 35(2), 99-118.

Berger, A. and C. Bouwman, 2009. Bank Liquidity Creation. Review of Financial Studies 22, 3779-3837.

Bhati, S., DeZoysa, A., \& Jitaree, W. (2015). Determinants of liquidity in nationalised banks of India. 〈world-finance-conference.com/papers_wfc/173.pdf〉

Bonfim, D., \& Kim, M. (2012). Liquidity risk in banking: is there herding? European Banking Center Discussion Paper, 2012-2024.

Brown, K. and Moles, P. (2012), Credit Risk Management, Edinburgh Business School, Heriot - Watt University, U.K

Boyd, J.H., De Nicoló, G., Smith, B.D., (2004). Crises in competitive versus monopolistic banking systems. Journal of Money, Credit and Banking 36, 487-506.

Bunda, I., \& Desquilbet, J. B. (2008). The bank liquidity smile across exchange rate regimes. International Economic Journal, 22(3), 361-386.

Cernohorsky., J. Teply, P. Chalupka, R. (2010). Operational Risk and Economic Capital Modeling. In: A.M. Rawani, et al (eds.). Proc. of Business, Economics and Tourism Management. Liverpool: World Academic Union. 70-75.

Chaplin, G., Emblow, A., \& Michael, I. (2000). Banking system liquidity: developments and issues. Financial Stability Review, 4, 93-112.

Choon, L. K., Hooi, L. Y., Murthi, L., Yi, T. S., Shven, T. Y. (2013). The determinants influencing liquidity of Malaysia commercial banks, and its

implication for relevant bodies: evidence from 15 Malaysian commercial banks. 〈http://eprints.utar.edu.my〉.

Diamond, D. W., \& Rajan, R. G. (2001). Liquidity risk, liquidity creation, and financial fragility: A theory of banking. Journal of political Economy, 109(2), 287-327.

Dinger, V. (2009). Do foreign-owned banks affect banking system liquidity risk?. Journal of Comparative 
Economics, 37(4), 647-657.

Distinguin, I., Roulet, C., \& Tarazi, A. (2013). Bank regulatory capital and liquidity: Evidence from US and European publicly traded banks. Journal of Banking \& Finance, 37(9), 3295-3317.

Ghosh, S. (2016). Capital buffer, credit risk and liquidity behaviour: evidence for GCC banks. Comparative Economic Studies, 58(4), 539-569.

Hakimi, A., \& Zaghdoudi, K. (2017). Liquidity Risk and Bank Performance: An Empirical Test for Tunisian Banks. Business and Economic Research, 7(1), 46-57.

Horvath, R., J. Seidler and L. Weill, (2014) Bank Capital and Liquidity Creation: Granger Causality Evidence. Journal of Financial Services Research 45, 3, 341-361.

Horvath, R., Seidler, J., \& Weill, L. (2016). How bank competition influences liquidity creation. Economic Modelling, 52, 155-161.

Jenkinson, N. (2008). Strengthening regimes for controlling liquidity risk: some lessons from the recent turmoil. Bank of England Quarterly Bulletin, 48(2).

Jokipii, T. and A. Milne, (2011). The Cyclical Behavior of European Bank Capital Buffers. Journal of Banking and Finance 32, 8, 1440-1451.

Kouki, I., \& Al-Nasser, A. (2017). The implication of banking competition: Evidence from African countries. Research in International Business and Finance, 39, 878-895.

Louati, S., Abida, I. G., \& Boujelbene, Y. (2015). Capital adequacy implications on Islamic and nonIslamic bank's behavior: Does market power matter?. Borsa Istanbul Review, 15(3), 192-204.

Melese, N. \& Laximikantham (2015). Determinants of Banks Liquidity: Empirical Evidence on Ethiopian Commercial Banks. Journal of Economics and Sustainable Development, 6(15), 36-46.

Moussa, M. A. B. (2015). The determinants of bank liquidity: case of Tunisia. International Journal of Economics and Financial Issues, 5(1), 249.

Repullo, R., (20015). Liquidity, Risk Taking, and the Lender of Last Resort. MPRA Pap er No. 826, p osted 14. 47-80

Singh, A., \& Sharma, A. K. (2016). An empirical analysis of macroeconomic and bank-specific factors affecting liquidity of Indian banks. Future Business Journal, 2(1), 40-53.

Tan, Y., Tan, Y., Anchor, J., \& Anchor, J. (2017). Does competition only impact on insolvency risk? New evidence from the Chinese banking industry. International Journal of Managerial Finance, 13(3), 332-354.

Tseganesh, T. (2012). Determinants of Banks Liquidity and their Impact on Financial Performance: empirical study on commercial banks in Ethiopia (Doctoral dissertation, aau)

Trenca, I., Petria, N., \& Corovei, E. A. (2015). Impact of Macroeconomic Variables upon the Banking System Liquidity. Procedia Economics and Finance, 32, 1170-1177.

Valla, N., Saes-Escorbiac, B. É.A. T.R. I.C. E., \& Tiesset, M. (2006). Bank liquidity and financial stability. Banque de France Financial Stability Review, 89-104.

Vodova, P. (2011). Liquidity of Czech commercial banks and its determinants. International Journal of Mathematical Models and Methods in Applied Sciences, 5(6), 1060-1067.

Zaghdoudi, K., \& Abdelaziz, H. (2017). Determinants of Banks Liquidity: Empirical Evidence on Ethiopian Commercial Banks. Journal of Applied Finance \& Banking, 7(2), 71-81. 